\title{
The Relationship of Cigarette Addiction, Smartphone Addiction and Self-Control of Men's Dormitory Students
}

\author{
Andreas Wisnu Adi Purnomo, J.T. Lobby Loekmono \\ Universitas Kristen Satya Wacana, Salatiga, Indonesia \\ andreaswisnu55@gmail.com
}

Submitted: 2020-08-18, Revised: 2020-09-04, Accepted: 2020-11-28

\begin{abstract}
This study aims to determine whether there is a significant relationship between cigarette addiction, simultaneous smartphone addiction and self-control. The subjects who became respondents were students who live in the male dormitory of Satya Wacana Christian University, totalling 109 students as the population. The sampling technique chosen was purposive sampling with the criteria of students who were active smokers and were involved in using smartphones. The research method used is correlational quantitative. The sample consisted of 33 students. The analysis technique used is the multiple correlation formula. Based on the results of various correlation analyzes, the R-value is -0.350 in the opposite direction. For comparison, the Fcount value is found to be 2.128 and the $\mathrm{F}$ table with a significant $5 \%$ of 4,130 . In other words, Fcount <Ftable, which means there is no significant relationship. The results of this study found that there was no significant relationship between cigarette addiction, simultaneous smartphone addiction and self-control.
\end{abstract}

Keywords: Cigarette Addiction; Self-Control; Smartphone Addiction

() 2020 KONSELI: Jurnal Bimbingan dan Konseling (E-Journal)

\section{Introduction}

Smoking is one of the behaviours that are often found in Indonesian society first among adults. Based on data from the Tobbaco Atlas (Masita \& Santosa, 2019), Indonesia is ranked 3rd in the world with the MOST number of smokers. This is, of course, a health problem for Indonesia, seeing various research results that show that the impact is harmful to human health. This is even more so when the sick individual has entered the category of dependence on cigarettes. Individual support on something can be controlled when they have good selfcontrol. Self-control is needed to help individuals overcome limited abilities and assist in overcoming adverse events that occur from outside (Choi, 2018; Harahap, 2017). One of the uses for self-control is to help individuals resist the urge to smoke. This control will help individuals realize the dangers of smoking itself so that individuals do not carry out these activities. Self-control means the individual's ability to change or ignore his instinctive responses or urges. Self-control possessed by individuals can prevent individuals from problems that result from impulses or impulses for a moment (Baumeister, 2017).

In addition to a large number of Indonesian smokers, people's lives in Indonesia today are inseparable from the use of smartphones or often referred to as smartphones for purposes such as online learning, communication via social media, reading books online, online shopping and online payments. All of these activities require the individual concerned to have a device, namely a smartphone so that the goals to be achieved can be achieved. The results of research conducted by We Are Social (Haryanto, 2020) in 2020 showed that $94 \%$ of the 175.4 million internet users in Indonesia with a user age range consisting of 16-60 years, access the internet using smartphone tools. This research shows that there are 164.8 million smartphone users actively accessing the internet. The high level of smartphone use makes individuals vulnerable to smartphone addiction; this is because smartphone use has a significant effect on 
smartphone addiction (A. P. Sari, Ilyas, \& Ifdil, 2017). The individual's self-control also influences the intensity in behaving over himself. Self-control is an alternative to be a solution so that individuals stay afloat and regulate their emotional responses so they can face all activities (P. Sari, Bulantika, \& Prasetyaning, 2020).

Based on a preliminary study conducted by researchers at the male dormitory of the Satya Wacana Christian University through observations and interviews with residents of the male dormitory and their administrators, it is known that male students in the dormitory spend their free time smoking and playing on smartphones. Also, the men's unit also received a warning for the commotion they made for playing online games using their smartphones from night to morning. There were even students who skipped college because they played all night with their smartphones. All activities that are useless and should not be carried out by dormitory residents are considered very important to be completed; this is because there is no self-control exercised by students who live in the dormitory. Based on the results of the preliminary study, researchers are interested in examining the relationship between cigarette dependence, smartphone addiction, and self-control of students who live in the male dormitory of the Satya Wacana Christian University.

Previous research conducted on 165 students at Brawijaya University, regarding the relationship between self-control and the tendency of smartphone addiction in students showed that there was a significant relationship and had the opposite direction between self-control and the disposition of student smartphone addiction. This is not known from the results of the analysis without new data or not of -0.609 and a value ( $p$ <.05) (Ilham, 2018). Another study regarding self-control is a study entitled The Relationship Between Self-Control and the Intensity of Smoking Behavior in Boys in Banda Aceh, the results of this study indicate that there is a significant relationship between smoking intentions and self-control with smartphone addiction (Juarni, 2016). Self-control is very influential on individual control of the activities carried out. This control will later help individuals to withstand all useless activities or activities that should not be done.

Another study on the relationship between self-control and smartphone or smartphone addiction in students is shown from the results of the study, the analysis indicates that the income coefficient or rxy is -0.253 and a p-value of 0.012 with a significance level of $<0.05$ is significant. Based on this study, it was found that there was a substantial relationship between self-control and student smartphone addiction (Lestari, 2018). Other research that examines the relationship between self-control and behaviour shows a significant relationship (Nurkumalasari, 2018). This study also indicates that there is a significant relationship between self and smartphone addiction (Nurherawati, 2020). So that self-control is needed by individuals in daily activities so that all activities are carried out by applicable norms and by ethical behaviour in each developmental task at the development stage.

Referring to the results of the literature review and preliminary studies, it was found that most of the research results indicated that there was a significant relationship between individual self-control and cigarette dependence or self-control with smartphones. Based on the results of these studies, the researcher proposes a hypothesis that there is a significant relationship between cigarette dependence, smartphone addiction and simultaneous selfcontrol. 


\section{Methods}

This research uses a quantitative approach with a correlational type. The purpose of this study was to prove whether there was a significant relationship between the dependent variable on smoking, smartphone addiction and the variable of self-control simultaneously. The independent variable (X1) in this study consisted of cigarette addiction, and (X2) smartphone addiction. In comparison, the dependent variable (Y) in this study is self-control. The population in this study was 109 students consisting of various faculties at the Satya Wacana Christian University, male dormitory residents. Sampling using purposive sampling, namely selection, by determining specific criteria by the research objectives. The measures determined by the researcher were students who smoked actively and actively used smartphones. From the purposive sampling, there were 33 students. The instrument used in this study was The Cigarette Addiction Scale, a 5-item short version (CDS-5) made by Jean-Francois Etter (Etter, 2003). For the instrument of smartphone addiction using The Smartphone Addiction Scale Short Revision (SAS-SV) made by Min Kwon, et al. (Kwon, 2013). Meanwhile, the selfcontrol instrument uses The Brief Self-Control Scale (BSCS) by Tangney, et al.(Boone, 2004).

Before being used to retrieve data, first go through the adaptation stage. The instrument adaptation stage begins with the translation of the statement items into Indonesian. Furthermore, the translation of the translation back into the original language of the instrument or called a re-translation by fellow researchers. They mastered English to check the similarity of meaning of the instrument statement items. After the language instrumentation process, the researcher tested the instrument, which could be seen the reliability of the device and the validity of an instrument item. Instrument testing was conducted two times; this is because in the trials the instrument reliability coefficient and validity per item of the instrument (CDS-5), (SAS-SV), and (BSCS) did not meet the criteria used by the researcher, so the researcher make revisions to the language translation that has been done, then do another test with a different subject. The benchmark reliability coefficient used by the researcher is $(0.8)$ which means that the instrument reliability is in a suitable category (Azwar, 2012) and the minimum item validity coefficient (0.3) is declared valid (Azwar, 2012).

Based on the second instrument trial, it was found that the Cronbach Alpha reliability coefficient of (CDS-5) was (0.827) and the validity coefficient per item moved from a score of 0.455 to $0.820(\mathrm{~N}=38)$. For (SAS-SV), the reliability coefficient is $(0.814)$, and the validity coefficient per item moves from 0.302 to $0.698(\mathrm{~N}=30)$. As for the instrument (BSCS), the reliability coefficient was (0.802), and the validity coefficient per item moved from 0.304 to $0.685(\mathrm{~N}=31)$. Referring to the instrument reliability coefficient and the validity of each research instrument item that has been tested, the instruments used in this study are declared valid and reliable.

The data analysis presented in this study consisted of descriptive and statistical analysis. The statistical analysis technique used to see the relationship simultaneously uses multiple analysis formulas. Meanwhile, the partial relationship analysis used the bivariate analysis technique with the Pearson product-moment formula utilising the help of SPSS version 20. For multiple or multiple correlation analysis, it was done manually.

\section{Results and Discussion}

Before the correlation analysis was carried out, the normality test was carried out on the three variables, namely self-control, smartphone addiction and cigarette addiction. The results of the normality test show that the sig value of the three variables is more than 0.05 , which means that the data is normally distributed. Then the hypothesis testing is continued using bivariate analysis. 
Table 1. Results of Bivariate Analysis

\begin{tabular}{|c|c|c|c|c|}
\hline \multicolumn{5}{|c|}{ Correlations } \\
\hline & & Cigarette & Smartphone & Control \\
\hline \multirow[t]{3}{*}{ Cigarette } & Pearson Correlation & 1 & .186 & -.178 \\
\hline & Sig. (2-tailed) & & .300 & .322 \\
\hline & $\mathrm{N}$ & 33 & 33 & 33 \\
\hline \multirow{3}{*}{ Smartphone } & Pearson Correlation & .186 & 1 & -.332 \\
\hline & Sig. (2-tailed) & .300 & & .059 \\
\hline & $\mathrm{N}$ & 33 & 33 & 33 \\
\hline \multirow[t]{3}{*}{ Control } & Pearson Correlation & -.178 & -.332 & 1 \\
\hline & Sig. (2-tailed) & .322 & .059 & \\
\hline & $\mathrm{N}$ & 33 & 33 & 33 \\
\hline
\end{tabular}

Based on Table 1, it is found that the correlation coefficient value between variables is partial. The correlation coefficient of the dependent variable on smoking with self-control is 0.178 with a sig. 0.322 , which means that the direction of the relationship between the dependent variable on smoking and self-control is contrary to the fragile closeness category, and there is no significant relationship. The correlation coefficient of the smartphone addiction variable with self-control is -0.332 sig. 0.059 , which means that the direction of the relationship between the smartphone addiction variable and self-control is different from the weak closeness category, and there is no significant relationship. Meanwhile, the correlation coefficient of the relationship between the dependent variable on smoking and smartphone addiction is 0.186 with a sig value. 0.300 , which means that the direction of the relationship between cigarette dependence and smartphone addiction is unidirectional or positive with the closeness category is very weak and does not have a significant relationship. This finding further confirms that there is a positive or unidirectional relationship in the problem of addiction or dependence. Also, this is an indication that when an individual experiences one dependency, another dependency will follow. The results showed that there was a positive direction between smartphone addiction and cigarette addiction.

Cigarette dependence is an individual's inability to quit smoking even though the individual doesn't actually want to smoke. The World Health Organization (WHO) in the International Statistical Classification of Diseases defines dependence as an experience of impaired self-control over things such as alcohol consumption or drug use and substances that have other addictive effects (Carvalho, Heilig, Perez, Probst, \& Rehm, 2019; Zou et al., 2017). This cigarette dependence occurs in all circles of society, from children to the elderly. Cigarette dependence is very detrimental to individuals and arises from various intrinsic and extrinsic factors.

The results showed that there was no relationship between self-control and cigarette addiction, this is by the results of the study which explained that there was no significant relationship between cigarette dependence and individual self-control (Wulaningsih \& Hartini, 2015). Good self-control does not necessarily support a person's ability to control the things he likes, for example, smoking. The more a person controls himself not to do things he likes, the deviant behaviours will be done. This is by the explanation that someone who cannot meet their needs will do a behaviour that is not by the norms prevailing in society (P. Sari, Suryawati, \& Bulantika, 2020). When an individual cannot fulfil his needs, wants or expectations, it will have an impact on his survival. Other problems will arise.

Apart from cigarette addiction, the problem discussed in this study is smartphone addiction. Smartphone addiction is excessive use of smartphones that is difficult for the user to control and hurts the life of the individual (Luk et al., 2018). The results showed that there was 
no relationship between smartphone addiction and student self-control in dormitories. This is by the results of research which explains that when stress increases, self-control decreases, which in turn leads to an increase in smartphone addiction (Cho, Kim, \& Park, 2017). Other studies have also explained that the causal relationship between smartphone addiction and school adjustment has not been clearly demonstrated (Heo \& Lee, 2018). The variables that become indicators of smartphone addiction include the duration of smartphone use and the individual's self-regulation (Gökçearslan, Mumcu, Haşlaman, \& Çevik, 2016).

This shows that someone who has good self-control may not necessarily be able to control himself not to use a smartphone for a long duration. The long duration of using a smartphone will have an impact on the ineffectiveness of the student learning process (Pabumbun \& Dalle, 2019; Pratama, Widianti, \& Hendrawati, 2020). The dormitory environment as the residence of the research subject has a culture or habit of smoking and playing games late at night; this is, of course, an indication that the environment and culture of the individual's residence being the research subject is related to individual self-control to smoke and play online games using a smartphone. Students already know that smartphone addiction will hurt their academic success, but they are not aware of the negative effects of smartphone addiction (Luk et al., 2018)

Self-control is an individual's ability to change circumstances and respond to situations experienced by the individual concerned (Agbaria \& Bdier, 2020). Therefore self-control is the key to the successful adaptation of individuals in their lives related to other individuals. The results of other studies show that providing support can reduce self-control in several ways (affecting persistence, focus, and feelings of tiredness), especially when there are concerns about effectiveness and the need to regulate emotions (Gosnell \& Gable, 2017). So, self-control is needed in all activities carried out by individuals; self-control can help individuals to find out behaviours that are by the demands of the community around the individual (Nurhaini, 2018; Titisari, 2018).

The results of the research that the author conducted have results that are contradictory to the research presented in previous research, where the results of previous studies show that there is a partially significant relationship between self-control and cigarette dependence and self-control with smartphone addiction. Other studies suggest that these three variables are interrelated and have a very close influence. Self-control is very influential on self-control so as not to do useless activities (Rambe, Mudjiran, \& Marjohan, 2017; Syaroh, 2019). The direction of the relationship between self-control and cigarette dependence is the opposite, which means that if a person's self-control is high, it will be followed by a low dependence on smoking and vice versa (Baumeister, 2017). The results of previous research also explain that the relationship between self-control and smartphone addiction is the opposite, which means that the higher the level of self-control a person has, the lower the level of smartphone addiction, and vice versa (Xiang et al., 2019). Self-control also helps individuals to carry out various kinds of activities that are felt to help individuals carry out activities in daily life. The difference in the results of this study is influenced by different participants and the number of less diverse samples. Cultural differences also greatly affect the self-control of research subjects so that it is necessary to use a more diverse sample so that the results can be maximized.

\section{Conclusions and Suggestions}

Based on the description of the research results, it is found that there are findings such as the correlation between smoking addiction and self-control with the opposite direction of the relationship with the closeness category is very weak and there is no significant relationship; the correlation between smartphone addiction and self-control with the opposite direction of the relationship with invalid closeness category and there is no significant 
relationship; the correlation between cigarette addiction and smartphone addiction which has a unidirectional relationship with the closeness category is very weak and has no significant relationship; and the correlation between smoking addiction, smartphone addiction, and selfcontrol simultaneously or simultaneously with the opposite direction and the invalid category and has no significant association.

Suggestions for other studies that examine the same topics and variables as this study. It is necessary to consider the number of samples and examine the effect of self-control variables on the dependent variable on smoking and smartphone addiction. In this study, the authors acknowledge the limitations of the number of samples used. This is because thes ituation is currently being hit by a pandemic and COVID 19, thus limiting the author from being able to meet the subject directly.

\section{References}

Agbaria, Q., \& Bdier, D. (2020). The role of self-control, social support and (positive and negative affects) in reducing test anxiety among Arab teenagers in Israel. Child Indicators Research, 13(3), 1023-1041.

Baumeister, R. F. (2017). Addiction, cigarette smoking, and voluntary control of action: Do cigarette smokers lose their free will? Addictive Behaviors Reports, 5, 67-84.

Carvalho, A. F., Heilig, M., Perez, A., Probst, C., \& Rehm, J. (2019). Alcohol use disorders. The Lancet, 394(10200), 781-792.

Cho, H., Kim, D. J., \& Park, J. W. (2017). Stress and adult smartphone addiction: Mediation by self-control, neuroticism, and extraversion. Stress and Health, 33(5), 624-630.

Choi, B. H. Y. (2018). Emotional Change Processes in Resolving Self-Critical Subtypes of Depression During Experiential Treatment.

Gökçearslan, Ş., Mumcu, F. K., Haşlaman, T., \& Çevik, Y. D. (2016). Modelling smartphone addiction: The role of smartphone usage, self-regulation, general self-efficacy and cyberloafing in university students. Computers in Human Behavior, 63, 639-649.

Gosnell, C. L., \& Gable, S. L. (2017). You deplete me: Impacts of providing positive and negative event support on self-control. Personal Relationships, 24(3), 598-622.

Harahap, J. Y. (2017). Hubungan Antara Kontrol Diri Dengan Ketergantungan Internet Di Pustaka Digital Perpustakaan Daerah Medan. JURNAL EDUKASI: Jurnal Bimbingan Konseling, 3(2), 131. https://doi.org/10.22373/je.v3i2.3091

Haryanto, A. T. (2020). Riset: ada 175, 2 juta pengguna internet di Indonesia. Diakses Dari Https://Inet. Detik. Com/Cyberlife/d-4907674/Risetada-1752-Juta-Pengguna-InternetDi-Indonesia.

Heo, Y., \& Lee, K. (2018). Smartphone addiction and school life adjustment among high school students: The mediating effect of self-control. Journal of Psychosocial Nursing and Mental Health Services, 56(11), 28-36.

Juarni, S. E. K. (2016). Hubungan Antara Kontrol Diri Dengan Intensitas Perilaku Merokok Pada Remaja Laki-laki di Banda Aceh, 2(1).

Lestari, T. P. (2018). Hubungan Antara Kontrol Diri Dan Kecanduan Telepon Pintar Pada 
Pada Mahasiswa.

Luk, T. T., Wang, M. P., Shen, C., Wan, A., Chau, P. H., Oliffe, J., ... Lam, T. H. (2018). Short version of the Smartphone Addiction Scale in Chinese adults: Psychometric properties, sociodemographic, and health behavioral correlates. Journal of Behavioral Addictions, 7(4), 1157-1165.

Masita, I. N., \& Santosa, H. P. (2019). Hubungan Terpaan Peringatan Risiko Bahaya Merokok pada Kemasan Rokok dan Intensitas Komunikasi Peer Group dengan Minat Berhenti Merokok Perempuan. Interaksi Online, 7(4), 226-235.

Nurhaini, D. (2018). Pengaruh konsep diri dan kontrol diri dengan perilaku konsumtif terhadap gadget remaja SMAN 1 Tanah Grogot. Ejournal. Psikologi. Fisip-Unmul. Ac. $I d, 6(1), 211-223$.

Nurherawati, N. (2020). Hubungan Antara Kontrol Diri dengan Kecanduan Smartphone Pada Mahasiswa Fakultas Psikologi. Universitas Ahmad Dahlan.

Nurkumalasari, O. (2018). Hubungan Antara Kontrol Diri dengan Kecenderungan Perilaku Merokok Pada Remaja Madya. Universitas Airlangga.

Pabumbun, A. R., \& Dalle, A. (2019). Problematika Pembelajaran Kemampuan Menyimak Bahasa Jerman Siswa Kelas XI SMAN 11 Makassar. Eralingua: Jurnal Pendidikan Bahasa Asing Dan Sastra, 1(2).

Pratama, R. A., Widianti, E., \& Hendrawati, H. (2020). Tingkat Kecanduan Game Online pada Mahasiswa Fakultas Keperawatan. Journal of Nursing Care, 3(2).

Rambe, S. A., Mudjiran, M., \& Marjohan, M. (2017). Pengembangan Modul Layanan Informasi untuk Mengembangkan Kontrol Diri dalam Penggunaan Smartphone. Konselor, 6(4), 132-137.

Sari, A. P., Ilyas, A., \& Ifdil, I. (2017). Tingkat Kecanduan Internet pada Remaja Awal. JPPI (Jurnal Penelitian Pendidikan Indonesia), 3(2), 110-117.

Sari, P., Bulantika, S. Z., \& Prasetyaning, F. (2020). Pengaruh Manajemen Stress dan Kelola Emosi Terhadap Tingkat Kecemasan Siswa di Masa New Normal, 2(2), 62-67.

Sari, P., Suryawati, C. T., \& Bulantika, S. Z. (2020). Internalisasi Nilai-nilai Piil Pesenggiri untuk Mencegah Perilaku Bullying Siswa SMK. Medikons: Jurnal Prodi Bimbingan Dan Konseling Unisri Surakarta, 6(1).

Syaroh, A. U. (2019). Faktor Kontrol Diri Dalam Penggunaan Gadget (Smartphone) Pada Siswa. Empati-Jurnal Bimbingan Dan Konseling, 6(2), 69-78.

Titisari, H. T. D. (2018). Hubungan antara Penyesuaian diri dan Kontrol diri dengan Perilaku Delikuen pada siswa SMA Muhammadiyah 1 Jombang. Psikodimensia, 16(2), 131-141.

Wulaningsih, R., \& Hartini, N. (2015). Hubungan antara persepsi pola asuh orangtua dan kontrol diri remaja terhadap perilaku merokok di pondok pesantren. Jurnal Psikologi Klinis Dan Kesehatan Mental, 4(2), 119-126.

Xiang, M.-Q., Lin, L., Wang, Z.-R., Li, J., Xu, Z., \& Hu, M. (2019). Sedentary Behavior and Problematic Smartphone Use in Chinese Adolescents: The Moderating Role of Self- 
Control. Frontiers in Psychology, 10.

Zou, Z., Wang, H., Uquillas, F. d'Oleire, Wang, X., Ding, J., \& Chen, H. (2017). Definition of substance and non-substance addiction. In Substance and Non-substance Addiction (pp. 21-41). Springer. 